\title{
Soils \& Fertilizers for Master Gardeners: Urban Soils and their Management Issues ${ }^{1}$
}

Amy L. Shober and Gurpal S. Toor ${ }^{2}$

This article is part of a series entitled Soils and Fertilizers for Master Gardeners. The rest of the series can be found at http://edis.ifas.ufl.edu/ topic_series_soils_and_fertilizers_for_master_garden ers. A glossary can also be found at http://edis.ifas.ufl.edu/MG457.

\section{Introduction and Purpose}

In a natural setting, soils provide a medium for plant root growth and perform a variety of physical and chemical functions including water movement and nutrient cycling. These soils also act as environmental filters by removing nutrients, chemicals, and pathogens from runoff water before they reach and pollute our lakes, rivers, oceans, or ground water. However, human activities in urban areas lead to soil disturbance, which alters the ability of the soils to function effectively. This publication describes the characteristics of urban soils and the associated management issues, specifically for soils in residential landscapes.

\section{Urban Soils in the Residential Landscape}

Natural soils form over a long period of time, ranging from decades to centuries, as a result of various soil forming factors (e.g., parent material, climate, topography, biological organisms, and time). However, during the course of urban development, activities such as land clearing, cutting, and filling drastically alter the natural soil habitat. Construction of residential sites often begins by removing all the native vegetation as well as the topsoil material. In some cases, fill material must be spread over the residential lot to allow for the construction of a home or home septic system. Fill material may consist of soils that were excavated during the construction of storm water ponds or it may be material that was hauled in from another location. As a result, fill material can vary widely in its physical and chemical properties. The home site is also compacted in order to be able to support the building structure. Topsoil removed at the beginning of the construction process may or may not be restored to the home site prior to the establishment of the home landscape. Also, in

1. This document is SL276, one of a series of the Soil and Water Science Department, Florida Cooperative Extension Service, Institute of Food and Agricultural Sciences, University of Florida. Original publication date December 2008. Revised January 2009. Visit the EDIS Web Site at http://edis.ifas.ufl.edu.

2. Amy L. Shober, assistant professor; Gurpal S. Toor, assistant professor, Center for Landscape Conservation \& Ecology, Soil and Water Science Department, Gulf Coast Research and Education Center, Florida Cooperative Extension Service, Institute of Food and Agricultural Sciences, University of Florida, Gainesville, FL 32611.

The Institute of Food and Agricultural Sciences (IFAS) is an Equal Opportunity Institution authorized to provide research, educational information and other services only to individuals and institutions that function with non-discrimination with respect to race, creed, color, religion, age, disability, sex, sexual orientation, marital status, national origin, political opinions or affiliations. U.S. Department of Agriculture, Cooperative Extension Service, University of Florida, IFAS, Florida A. \& M. University Cooperative Extension Program, and Boards of County Commissioners Cooperating. Millie Ferrrer, Interim Dean 
some cases, construction materials and other debris may be in the soil.

\section{Characteristics of Urban Soils}

The construction activities dramatically change the soil properties resulting in an "urban soil". An urban soil is "a soil material having a nonagricultural, manmade surface layer more than 50 centimeters ( 20 inches) thick that has been produced by mixing, filling, or by contamination of land surface in urban and suburban areas" (Maechling et al., 1974). Urban soils may exhibit the following altered characteristics:

\section{Physical}

1. Compaction (high bulk density)

2. Poor soil structure

3. High clay content

4. Surface crusting

5. High soil temperature

\section{Chemical}

1. High variability in nutrient content

2. Low soil organic matter

3. Low soil fertility

4. High $\mathrm{pH}$

\section{Biological}

1. Very few soil microorganisms

2. Little or no biological activity

\section{Major Management Issues Associated with Urban Soils}

\section{Soil Compaction}

The activities that impact soils in urban areas often result in the destruction of soil structure and an increase in bulk density. The result is soil compaction. Compacted soils are not ideal for plant growth. Compacted soils have reduced soil pore space and the associated issues with soil drainage and aeration. In addition, the increased bulk density and soil strength can make it difficult for plant roots to penetrate. As a result, it may be difficult or nearly impossible to re-establish native vegetation in compacted urban soils. Failure of sod and landscape plant material has been reported in new landscapes where soils have been significantly compacted. In addition, plants that manage to survive and grow in compacted soils may have increased water and fertilizer requirements and/or be more susceptible to pests and diseases. Compaction results in reduced infiltration of rain and irrigation water into the soil. Soil compaction can facilitate the formation of surface crusts, which further limit infiltration of water into urban soils. This increases the volume of polluted runoff in urbanizing areas. A greater volume of water also increases erosion, which can elevate sediment loads to urban streams and affect the survival of aquatic organisms.

\section{Disrupted Nutrient Cycling}

Changes in soil chemical properties can result in reduced availability of nutrients to landscape plants. This is partly caused by the disruption of soil nutrient cycling due to decreased abundance and activity of soil microorganisms. In addition, many plant residues are removed from urban landscapes and sent to municipal facilities for off-site recycling. As a result of reduced biological function and organic matter export, urban soils tend to have lower amounts of organic matter, which is a major source of nitrogen and phosphorus to growing plants. Therefore, urban landscapes often require more frequent applications of commercial fertilizers, thereby increasing the potential that some of the applied fertilizer may be lost in leachate or runoff.

\section{Elevated Soil pH}

Soils in an urban setting tend to be more alkaline than native soils. This may be partly due to the use of calcium-rich construction materials. As a result, soils near masonry walls tend to have an elevated $\mathrm{pH}$ and may be unsuitable for acid-loving plants. In some cases, construction debris like concrete or mortar may be buried in urban soils. This may result in pockets of soil where $\mathrm{pH}$ makes it difficult to establish 
landscape plants. Micronutrient deficiencies are common in strongly alkaline soils.

\section{Improving the Function of Urban Soils}

It is a challenge to rapidly reduce the impacts of urbanization on soil properties and it may take quite a while and extensive effort to improve soil quality. However, it does not mean it cannot be done! First of all, some of the physical and chemical properties of urban soils will improve with time as the landscape matures. Unfortunately, it may take many years for the conditions to improve.

Perhaps, the best strategy for homeowners is to gradually build soil organic matter, which will improve water holding capacity, nutrient cycling, biological activity, and water infiltration. One way to increase organic matter is to leave plant residues (such as grass clippings and leaves) on the soil and allow them degrade naturally. Alternatively, compost materials can be applied to the soil to achieve this goal. In established landscapes, composted materials can be applied to the surface of a turf or bedding plant area. As the material breaks down, it will move downward and be incorporated in the topsoil. When preparing new plant beds, compost can be mixed into the rooting zone. It is important that compost materials be well decomposed before they are incorporated into the soil, otherwise, the nitrogen present in the soil may be immobilized and unavailable to your plants. As a rule of thumb, compost should contain no recognizable bits of organic matter (e.g., whole leaves, sticks, or other large chunks). For more information about building organic matter with organic amendments, see EDIS publication MG454, Soil Organic Matter \& Organic Amendments (http:edis.ifas.ufl.edu/MG454).

Soil tillage can also help to improve the physical and chemical properties of urban soils. This may be impractical in established landscapes, but can be useful when preparing new beds or if you are renovating a large area of your landscape. However, you should never till soil in areas that contain trees roots, as this may cause serious harm to the trees. In established landscapes or areas with tree roots, it may be beneficial to aerate the soil using soil aerator. A soil aerator removes small plugs from the soil, which allows air and water to move into the soil.

\section{Summary}

Soils in urban areas are often impacted by human activities. The physical, chemical and biological properties of urban soils can be significantly disturbed when compared to natural soils. Major management issues for urban soils include soil compaction, disrupted nutrient cycling, and elevated soil $\mathrm{pH}$. Urban soil properties will slowly improve over time; however, homeowners can speed the process by increasing the organic matter content of the soils. This can be done by recycling plant residues in the home landscape or by applying compost materials to the soil.

\section{References}

Brown, R.B., J.H. Huddleston, and J.L. Anderson. 2000. Managing Soils in an Urban Environment. American Society of Agronomy, Madison, WI.

Craul, P.J. 1992. Urban Soil in Landscape Design. John Wiley \& Sons, Inc., New York, NY.

Maechling, P., Cooke, H. and Bockheim, J.G. 1974. Nature and properties of highly disturbed urban soils. p. 151. In Agronomy abstracts. ASA, CSSA, SSSA, Madison, WI. 